\title{
Hubungan antara Tayangan Youtube Saaih Halilintar dengan Gaya Hidup Hedonisme
}

\author{
Elmy Andrianti *, Indri Rachmawati \\ Prodi Manajemen Komunikasi, Fakultas Ilmu Komunikasi, Universitas Islam \\ Bandung, Indonesia. \\ *elmingyu0497@gmail.com, indri.rachmawati@unisba.ac.id
}

\begin{abstract}
Hedonism means a living outlook that considers pleasure and material bliss as the main purpose of life. In general, these hedonists assume that they only live once in a lifetime. Therefore, they have the need to enjoy life as pleasurable as possible, adn free with No. limits. New media is a medium that uses the internet, technology based online media that has flexible character, it also has the potential to interactive and can funcation privately or publicly. For this research, i conducted a quantitative method with a correlational approach that aims to determine the hedonism that is in accordance with the AIO indikator (Activities, Interest dan Opinion). Also, this study implements a sampling technique namely simple random sampling.
\end{abstract}

Keywords: Hedonism, New Media.

Abstrak. Hedonisme mempunyai arti pandangan hidup yang menganggap kesenangan dan kenikmatan materi adalah tujuan utama hidup. Pada umumnya, kaum hedonis ini beranggapan bahwa hidup ini hanya satu kali. Oleh karena itu, mereka merasa ingin menikmati hidup senikmat-nikmatnya, sebebas-bebasnya tanpa batas. New media merupakan media yang menggunakan internet, media online berbasis teknologi, berkarakter fleksibel, berpotensi interaktif dan dapat berfungsi secara privat maupun secara publik. Penelitian ini menggunakan metode kuantitatif dengan pendekatan korelasional yang bertujuan untuk mengetahui hedonisme yang sesuai dengan indikator AIO (Activities, Interest dan Opinion). Dalam penelitian ini menggunakan teknik pengambilan sampel dengan simple random sampling.

Kata Kunci: Hedonisme, New Media. 


\section{A. Pendahuluan}

Hedonisme sudah menjadi bagian dari gaya hidup dikalangan masyarakat Indonesia saat ini terutama dikalangan remaja. Gaya hidup hedonisme menimbulkan kecenderungan munculnya tingkal laku individu melalui interaksi sosial antara satu dengan individu lainnya, untuk memperoleh kesenangan dan kebebasan untuk mencapai kenikmatan hidup. Pada umumnya, kaum hedonis ini beranggapan bahwa hidup ini hanya satu kali. Oleh karena itu, mereka merasa ingin menikmati hidup senikmat-nikmatnya, sebebas-bebasnya tanpa batas. (Dewojati, 2010: 16). Melihat hal tersebut maka perlu adanya antisipasi dari orang tua. Semua orang sebenarnya memiliki gaya hidup hedonisme, yang membedakan adalah tingkatannya, hedonis sedang dan hedonis berat yang sudah menganggap bahwa kesenangan adalah tujuan dari kehidupannya.

Masalah inilah yang banyak meracuni remaja sekarang ini, gaya hidup hedonisme yang menganggap kepuasan materi menjadi tujuan utamanya. menurut Jean Piaget (dalam Ali\&Asrori 2015:87) mengatakan bahwa permulaan kerja sama dan konformisme yang artinya: menurut saja pada kebiasaan, aturan, atau cara berfikir yang dianut oleh kebanyakan anggauta masyarakat itu, tanpa difikir panjang) sosial semakin bertambah pada anak saat anak mencapai usia 7 samapi 10 tahun dan mencapai puncak kurva pada saat anak berada diantara umur $9-15$ tahun.

Jaringan internet sebagai new media secara signifikan mengubah perilaku komunikasi masyarakat. Salah satunya adalah dengan memenuhi kebutuhan informasi audio-visual. Salah satunya yang paling populer adalah Youtube. Youtube adalah sebuah situs web video sharing (berbagi video) populer di mana para pengguna dapat memuat, menonton, dan berbagi klip video secara gratis. Keanekaragaman topik yang ada di Youtube membuat berbagi video menjadi salah satu bagian yang penting dalam kultur berinternet (Tamburaka, 2013:83). Di zaman kekinian, tokoh idola masyarakat sudah tidak terpusat lagi pada public figure atau selebriti yang bermain di layar kaca atau televisi. Beberapa tokoh yang terkenal di platform online (termasuk content creator) pun kini sudah diakui sebagai selebriti.

Seberapa besar dampak terpaan media sosial dari youtube yang berfokus pada tayangan konten videonya dapat membentuk dan mempengaruhi gaya hidup hedonisme, membuat peneliti tertarik melakukan penelitian untuk mengetahui "Adakah hubungan terpaan media dengan gaya hidup hedonisme?" selanjutnya tujuan dari penelitian ini adalah :

1. Untuk mengetahui hubungan Frekuensi pada tayangan youtube Saaih Halilintar dengan Activities di kalangan remaja.

2. Untuk mengetahui hubungan Frekuensi pada tayangan youtube Saaih Halilintar dengan Interest di kalangan remaja.

3. Untuk mengetahui hubungan Frekuensi pada tayangan youtube Saaih Halilintar dengan Opinion di kalangan remaja.

4. Untuk mengetahui hubungan Durasi pada tayangan youtube Saaih Halilintar dengan Activities di kalangan remaja.

5. Untuk mengetahui hubungan Durasi pada tayangan youtube Saaih Halilintar dengan Interest di kalangan remaja.

6. Untuk mengetahui hubungan Durasi pada tayangan youtube Saaih Halilintar dengan Opinion di kalangan remaja.

7. Untuk mengetahui hubungan Atensi pada tayangan youtube Saaih Halilintar dengan Activities di kalangan remaja.

8. Untuk mengetahui hubungan Atensi pada tayangan youtube Saaih Halilintar dengan Interest di kalangan remaja.

9. Untuk mengetahui hubungan Atensi pada tayangan youtube Saaih Halilintar dengan Opinion di kalangan remaja

\section{B. Landasan Teori}

Terpaan media adalah intensitas keadaan dimana khalayak terkena atau terpapar oleh pesanpesan yang disebarkan melalui media (Effendy, 1990 dalam Puspitasari 2018:11). Terpaan dari suatu media mampu memberikan dampak yang dalam bagi penontonnya. Adanya pesan- pesan 
yang bersifat persuasif yang terlah disajikan sedemikian rupa dapat memicu terjadinya perubahan perilaku, sikap, pandangan maupun persepsi. Selain itu menurut Rosengren dalam Rakhmat (2009:66 dalam Amalia\&Pangstuti 2017), terpaan media juga dapat diukur melalui dimensi-dimensi seperti Frekuensi, durasi dan atensi.

Gaya hidup hedonisme adalah suatu pola hidup dimana aktivitasnya cenderung mencari kesenangan hidup, contohnya lebih banyak menghabiskan waktu di luar rumah, lebih banyak bermain, menyenangi keramaian kota, menyukai barang mahal, dan selalu ingin menjadi pusat perhatian (Chaney dalam Subandy, 1997: 56; Amstrong, 2003: 15; Nugraheni, 2003, Sudarsih, 2007). Individu dengan gaya hidup hedonis akan lebih mementingkan penampilan fisik. Berharap dengan tampil glamour akan menimbulkan kesan modern dan prestisius (Budiman, 2002: 172). (dalam Adhi 2017:26).

Dalam penelitian ini dimana dalam konten tayangan youtube Saaih Halilintar penonton disuguhi gaya hidup hedonisme, sehingga penelitian ini menjelaskan adakah hubungan terpaan media dengan gaya hidup hedonisme yang diukur dari activities, interest dan opinion.

\section{Metodologi}

Jenis penelitian yang digunakan adalah penelitian kuantitatif dengan studi korelasional, menurut Rakhmat (2014:31) adalah metode yang meneliti hubungan di antara berbagai variabel. Perbedaan antara korelasional dengan pendekatan penelitian lainnya adalah usaha untuk menafsirkan hubungan bukan sekedar mendeskripsikan saja. Di mana peneliti dapat mengetahui seberapa besar kontribusi variabel-variabel bebas (X) dengan variabel terikat (Y) serta besarnya hubungan terjadi. Untuk mengetahui hubungan antara variabel-variabel tersebut dapat diukur dengan menggunakan koefisien korelasi.

Dalam penelitian ini, populasi yang diambil adalah siswa/i kelas X SMA 3 Negeri Bekasi, sebanyak 337 siswa/i. SMA 3 Negeri Bekasi dipilih peneliti karena lokasi sekolahnya satu lingkungan dengan perumahan Grand Galaxy Bekasi yang dimana perumahan kelas menengah keatas. Populasi yang terdapat dalam penelitian ini berjumlah $337 \mathrm{siswa} / \mathrm{i}$ dan presisi yang ditetapkan atau tingkatan signifikan $10 \%$ atau 0,1 , dengan menggunakan rumus slovin maka besarnya sampel pada penelitian ini adalah 77 orang.

Teknik pengumpulan data pada penelitian ini melalui penyebaran angket. Kuesioner dibagikan melalui angket online kepada 77 siswa/i SMA 3 Negeri Bekasi yang telah ditentukan. Kuesioner yang dibuat berisi data responden dan pertanyaan-pertanyaan yang sesuia dengan objek penelitian. Penelitian ini dapat dilakukan dengan menggunakan skala likert $(1=$ tidak pernah sampai $5=$ selalu). Maka pernyataan dalam kuesioner masing-masing variabel dalam penelitian ini diukur dengan menggunakan skala likert. Dalam penelitian ini, selain melalui kuesioner peneliti mengumpulkan data juga melalui wawancara dengan salah satu responden dan studi kepustakaan.

\section{Hasil Penelitian dan Pembahasan}

Pengujian hipotesis dengan metode statistik ini dilakukan dengan memberi nilai pada setiap item pertanyaan dan membuat pasangan data berdasarkan subvariabel yang ada pada angket yang telah disebarkan untuk mencari ada atau tidaknya hubungan antar variabel. Dalam penelitian ini jenis data yang diperoleh memiliki karakteristik ordinal-ordinal, dengan demikian perhitungan statistik dapat digunakan dengan teknik korelasi Rank Spearman.

Selanjutnya, untuk menentukan tingkat keeratan hubungan antara kedua variabel dapat berpedoman pada tabel berdasarkan interpretasi Koefisian Korelasi (Guilford, 1956:145 dalam Rakhmat 2014:29) sebagai berikut:

\begin{tabular}{|l|l|}
\hline Nilai Korelasi & Keterangan \\
\hline Kurang dari 0,20 & Hubungan rendah sekali \\
\hline
\end{tabular}




\begin{tabular}{|l|l|}
\hline $0,20-0,40$ & Hubungan rendah tetapi pasti \\
\hline $0,40-0,70$ & Hubungan yang cukup berarti \\
\hline $0,70-0,90$ & Hubungan yang tinggi \\
\hline Lebih dari 0,90 & Hubungan sangat tinggi \\
\hline
\end{tabular}

Berikut merupakan hasil perhitungan nilai korelasi untuk menjawab hipotesis yang diajukan:

\begin{tabular}{|c|c|c|c|}
\hline Variabel & Statistik uji & kesimpulan & Keterangan \\
\hline $\begin{array}{l}\mathrm{H}_{0} \text { :Tidak terdapat } \\
\text { hubungan antara } \\
\text { frekuensi dengan } \\
\text { activities } \\
\mathrm{H}_{1} \text { : Terdapat hubungan } \\
\text { antara frekuensi dengan } \\
\text { activities }\end{array}$ & $\begin{array}{l}\text { Rs }=0,281 \\
\text { T hitung }(3,231)> \\
\text { T tabel }(1,864)\end{array}$ & $\mathrm{H}_{0}$ ditolak & $\begin{array}{l}\text { Mengacu pada kriteria } \\
\text { Guildford, nilai koefisien } \\
\text { hubungan antara frekuensi } \\
\text { dengan avtivities sebesar } \\
0,281 \text { berada diantara } 0,20 \text { - } \\
0,40 \text { yang menunjukkan } \\
\text { hubungan cukup rendah tapi } \\
\text { pasti }\end{array}$ \\
\hline $\begin{array}{l}\mathrm{H}_{0} \quad \text { : Tidak terdapat } \\
\text { hubungan antara } \\
\text { frekuensi dengan } \\
\text { interest } \\
\mathrm{H}_{1} \quad \text { : Terdapat } \\
\text { hubungan antara } \\
\text { frekuensi dengan } \\
\text { interest }\end{array}$ & $\begin{array}{l}\text { Rs }=0,311 \\
\text { T hitung }(3,142)> \\
\text { T tabel }(1,864)\end{array}$ & $\mathrm{H}_{0}$ ditolak & $\begin{array}{l}\text { Mengacu pada kriteria } \\
\text { Guildford, nilai koefisien } \\
\text { hubungan antara frekuensi } \\
\text { dengan avtivities sebesar } \\
0,311 \text { berada diantara } 0,20 \text { - } \\
0,40 \text { yang menunjukkan } \\
\text { hubungan cukup rendah tapi } \\
\text { pasti }\end{array}$ \\
\hline $\begin{array}{l}\mathrm{H}_{0} \quad \text { : Tidak terdapat } \\
\text { hubungan antara } \\
\text { frekuensi dengan opini } \\
\mathrm{H}_{1} \quad \text { : Terdapat } \\
\text { hubungan antara } \\
\text { frekuensi dengan opini }\end{array}$ & $\begin{array}{l}\text { Rs }=0,309 \\
\text { T hitung }(3,158)> \\
\text { T tabel }(1,864)\end{array}$ & $\mathrm{H}_{0}$ ditolak & $\begin{array}{l}\text { Mengacu pada kriteria } \\
\text { Guildford, nilai koefisien } \\
\text { hubungan antara frekuensi } \\
\text { dengan avtivities sebesar } \\
0,309 \text { berada diantara } 0,20 \text { - } \\
0,40 \text { yang menunjukkan }\end{array}$ \\
\hline
\end{tabular}




\begin{tabular}{|c|c|c|c|}
\hline Variabel & Statistik uji & kesimpulan & Keterangan \\
\hline & & & $\begin{array}{l}\text { hubungan cukup rendah tapi } \\
\text { pasti }\end{array}$ \\
\hline $\begin{array}{l}\mathrm{H}_{0} \quad \text { : Tidak terdapat } \\
\text { hubungan antara durasi } \\
\text { dengan activities } \\
\mathrm{H}_{1} \quad \text { : Terdapat } \\
\text { hubungan antara durasi } \\
\text { dengan activities }\end{array}$ & $\begin{array}{l}\text { Rs }=0,386 \\
\text { T hitung }(2,241)> \\
\text { T tabel }(1,864)\end{array}$ & $\mathrm{H}_{0}$ ditolak & $\begin{array}{l}\text { Mengacu pada kriteria } \\
\text { Guildford, nilai koefisien } \\
\text { hubungan antara frekuensi } \\
\text { dengan avtivities sebesar } \\
0,386 \text { berada diantara } 0,20 \text { - } \\
0,40 \text { yang menunjukkan } \\
\text { hubungan cukup rendah tapi } \\
\text { pasti }\end{array}$ \\
\hline $\begin{array}{l}\mathrm{H}_{0} \quad \text { : Tidak terdapat } \\
\text { hubungan antara durasi } \\
\text { dengan interest } \\
\mathrm{H}_{1} \quad \text { : Terdapat } \\
\text { hubungan antara durasi } \\
\text { dengan interest }\end{array}$ & $\begin{array}{l}\text { Rs }=0,374 \\
\text { T hitung }(3,331)> \\
\text { T tabel }(1,864)\end{array}$ & $\mathrm{H}_{0}$ ditolak & $\begin{array}{l}\text { Mengacu pada kriteria } \\
\text { Guildford, nilai koefisien } \\
\text { hubungan antara frekuensi } \\
\text { dengan avtivities sebesar } \\
0,374 \text { berada diantara } 0,20 \text { - } \\
0,40 \text { yang menunjukkan } \\
\text { hubungan cukup rendah tapi } \\
\text { pasti }\end{array}$ \\
\hline $\begin{array}{l}\mathrm{H}_{0} \quad \text { : Tidak terdapat } \\
\text { hubungan antara durasi } \\
\text { dengan opini } \\
\mathrm{H}_{1} \quad \text { : Terdapat } \\
\text { hubungan antara durasi } \\
\text { dengan opini }\end{array}$ & $\begin{array}{l}\text { Rs }=0,368 \\
\text { T hitung }(2,337)> \\
\text { T tabel }(1,864)\end{array}$ & $\mathrm{H}_{0}$ ditolak & $\begin{array}{l}\text { Mengacu pada kriteria } \\
\text { Guildford, nilai koefisien } \\
\text { hubungan antara frekuensi } \\
\text { dengan avtivities sebesar } \\
0,386 \text { berada diantara } 0,20 \text { - } \\
0,40 \text { yang menunjukkan } \\
\text { hubungan cukup rendah tapi } \\
\text { pasti }\end{array}$ \\
\hline $\begin{array}{l}\mathrm{H}_{0} \quad \text { : Tidak terdapat } \\
\text { hubungan antara atensi } \\
\text { dengan activities }\end{array}$ & $\begin{array}{l}\text { Rs }=0,389 \\
\text { T hitung }(2,541)> \\
\text { T tabel }(1,864)\end{array}$ & $\mathrm{H}_{0}$ ditolak & $\begin{array}{l}\text { Mengacu pada kriteria } \\
\text { Guildford, nilai koefisien } \\
\text { hubungan antara frekuensi } \\
\text { dengan avtivities sebesar } \\
0,389 \text { berada diantara } 0,20 \text { - } \\
0,40 \text { yang menunjukkan }\end{array}$ \\
\hline
\end{tabular}




\begin{tabular}{|c|c|c|c|}
\hline Variabel & Statistik uji & kesimpulan & Keterangan \\
\hline $\begin{array}{l}\mathrm{H}_{1} \quad: \text { Terdapat } \\
\text { hubungan antara atensi } \\
\text { dengan activities }\end{array}$ & & & $\begin{array}{l}\text { hubungan cukup rendah tapi } \\
\text { pasti }\end{array}$ \\
\hline $\begin{array}{l}\mathrm{H}_{0} \quad \text { : Tidak terdapat } \\
\text { hubungan antara atensi } \\
\text { dengan interest } \\
\mathrm{H}_{1} \quad \text { : Terdapat } \\
\text { hubungan antara atensi } \\
\text { dengan interest }\end{array}$ & $\begin{array}{l}\text { Rs }=0,402 \\
\text { T hitung }(3,572)> \\
\text { T tabel }(1,864)\end{array}$ & $\mathrm{H}_{0}$ ditolak & $\begin{array}{l}\text { Mengacu pada kriteria } \\
\text { Guildford, nilai koefisien } \\
\text { hubungan antara frekuensi } \\
\text { dengan avtivities sebesar } \\
0,402 \text { berada diantara } 0,40 \text { - } \\
0,70 \text { yang menunjukkan } \\
\text { hubungan yang cukup pasti }\end{array}$ \\
\hline $\begin{array}{l}\mathrm{H}_{0} \quad \text { : Tidak terdapat } \\
\text { hubungan antara atensi } \\
\text { dengan opini } \\
\mathrm{H}_{1} \quad \text { : Terdapat } \\
\text { hubungan antara atensi } \\
\text { dengan opini }\end{array}$ & $\begin{array}{l}\text { Rs }=0,343 \\
\text { T hitung }(3,012)> \\
\text { T tabel }(1,864)\end{array}$ & $\mathrm{H}_{0}$ ditolak & $\begin{array}{l}\text { Mengacu pada kriteria } \\
\text { Guildford, nilai koefisien } \\
\text { hubungan antara frekuensi } \\
\text { dengan avtivities sebesar } \\
0,343 \text { berada diantara } 0,20 \text { - } \\
0,40 \text { yang menunjukkan } \\
\text { hubungan cukup rendah tapi } \\
\text { pasti }\end{array}$ \\
\hline
\end{tabular}

\section{Kesimpulan}

Berdasarkan hasil pengujian sub hipotesis dalam penelitian, dapat ditarik beberapa kesimpulan sebagai berikut:

1. Terdapat hubungan antara frekuensi dengan activities dengan kekuatan hubungan rendah tapi pasti. Responden semakin besar intensitas menonton video Saaih Halilintar yang diterima semakin besar pula mempengaruhi activities.

2. Terdapat hubungan antara frekuensi dengan interest dengan kekuatan hubungan rendah tapi pasti. Responden semakin besar intensitas menonton video Saaih Halilintar yang diterima semakin besar pula mempengaruhi interest.

3. Terdapat hubungan antara frekuensi dengan opini dengan kekuatan hubungan rendah tapi pasti. Responden semakin besar intensitas menonton video Saaih Halilintar yang diterima semakin besar pula mempengaruhi opini.

4. Terdapat hubungan antara durasi dengan activities dengan kekuatan hubungan rendah tapi pasti. Responden semakin besar lama dan sering menonton video Saaih Halilintar yang diterima semakin besar pula mempengaruhi activities.

5. Terdapat hubungan antara durasi dengan interest dengan kekuatan hubungan rendah tapi pasti. Responen semakin besar lama dan sering menonton video Saaih Halilintar yang 
diterima semakin besar pula mempengaruhi interest.

6. Terdapat hubungan antara durasi dengan opini dengan kekuatan hubungan rendah tapi pasti. Responden semakin besar lama dan sering menonton video Saaih Halilintar yang diterima semakin besar pula mempengaruhi opini.

7. Terdapat hubungan antara atensi dengan activities dengan kekuatan hubungan rendah tapi pasti. Responden semakin besar perhatian yang diberikan pada saat menonton video Saaih Halilintar yang diterima semakin besar pula mempengaruhi activities.

8. Terdapat hubungan antara atensi dengan interest dengan kekuatan hubungan yang cukup berarti. Responden semakin besar perhatian yang diberikan pada saat menonton video Saaih Halilintar yang diterima semakin besar pula mempengaruhi interest.

9. Terdapat hubungan antara atensi dengan opini dengan kekuatan hubungan rendah tapi past. Responden semakin besar perhatian yang diberikan pada saat menonton video Saaih Halilintar yang diterima semakin besar pula mempengaruhi opini.

\section{Daftar Pustaka}

[1] Dewojati, Cahyaningrum.2010. Wacana Hedonisme.Pustaka Pelajar: Yogyakarta

[2] Ali, Mohammad\&Asrori, Mohammad. 2015. Psikologi Remaja. PT. Bumi Akrasa. Jakarta

[3] Tamburaka, Apriadi.2013. Literasi Media: Cerdas Bermedia Khalayak Media, PT. Raya Grafindo Persada

[4] Puspitasari, Dinda, 2018. Pengaruh terpaan video beauty vlogger diyoutube terhadap perilaku imitasi mahasiswi dalam merias wajah.

[5] Adhi, Oktaviani.2017. Hedonisme dan Konsumerisme dalam Perspektif Dramaturgi Erving Goffman. Volume 2, No. 1, 2017, hlm 26

[6] Rakhmat, Jalaluddin. 2014. Metode Penelitian Komunikasi: Dilengkapi Contoh Analisis Statistik. Bandung: PT. Remaja Rosdakarya. 